Note

\section{Determination of Green Leaf Carotenoids by $\mathrm{HPLC}^{\dagger}$}

\author{
Shigeaki TAKAGI \\ Department of Agricultural Chemistry, \\ Faculty of Agriculture, \\ Okayama University, \\ Okayama 700, Japan
}

Received August 30, 1984

Lutein, one of the major carotenoids in green leaves, associates upon dispersion in water to form a large helical aggregate which induces strong circular dichroism (CD) in the visible region. ${ }^{1 \sim 6)}$

Quantitative determination for each carotenoid of green leaves is essential to pursue the function and the role of lutein molecule in thylakoid membranes.

A number of papers ${ }^{714)}$ on liquid chromatography for analysis of leaf carotenoids have been published. These methods, however, involve no quantitative concept. The author presents a new technique for a high performance liquid chromatographic (HPLC) system permitting simultaneous determination of major leaf carotenoids with simplicity and reproducibility using silica gel columns.

Authentic carotenoids were obtained as follows; $\beta$ carotene ( $\beta, \beta$-carotene) was purchased from Merck, and lutein $\left(\beta, \varepsilon\right.$-carotene $3,3^{\prime}$-diol $){ }^{15)}$ violaxanthin $\left(5,6,5^{\prime}, 6^{\prime}\right.$ diepoxy-5,6,5',6'-tetrahydro- $\beta, \beta$-carotene-3,3'-diol), neoxanthin $\quad\left(5^{\prime}, 6^{\prime}\right.$-epoxy-6,7-didehydro-5,6,5',6'-tetrahydro$\beta, \beta$-carotene-3,5,3'-triol) ${ }^{16)}$ and crocetin $\left(8,8^{\prime}\right.$ diapocarotene-8, $8^{\prime}$-dioic acid) were isolated from spinach leaves by preparative column chromatography. Carotenoid extraction from leaves was carried out substantially according to the ordinary method. ${ }^{17,18)}$ Less than $10 \mathrm{~g}$ of fresh green leaves were homogenized with $150 \mathrm{ml}$ acetone and kept at room temperature for $1 \mathrm{hr}$ in the dark. The homogenate was filtered through filter paper by suction. Extraction was repeated three times with the same volume of acetone. The extracts were combined and evaporated under reduced pressure, and the residue was reextracted by a mixture of diethyl ether and petroleum ether $(1: 1)$. The extract was dried over anhydrous sodium sulfate, concentrated by evaporation, and filled up to $20 \mathrm{ml}$ with acetone. Chlorophylls were determined with the acetone solution according to the method of Wintermans et al. ${ }^{19)}$ if necessary. Five $\mathrm{ml}$ of the acetone solution was saponified with $25 \mathrm{ml}$ of $1 \mathrm{~N}$ ethanolic solution of potassium hydroxide at $20^{\circ} \mathrm{C}$ for $8 \mathrm{hr}$ in the dark. After addition of an equal volume of distilled water, unsaponified substances were extracted with a mixture of diethyl ether and petroleum ether $(1: 1)$ three times, followed by washing of the extract with small volume of aqueous saturated solution of sodium chloride three times. The extract was dried over anhydrous sodium sulfate, concentrated by evaporation, and filled up to $5 \mathrm{ml}$ with solvent A, the initial solvent for HPLC. Irrespective of the saponification time $(7 \sim 24 \mathrm{hr})$, the determined values of the individual carotenoids were almost constant, so saponification at $20^{\circ} \mathrm{C}$ for $8 \mathrm{hr}$ was used throughout the experiments.

HPLC was run on a Hitachi 638 instrument with a stainless steel column of $0.3 \mathrm{~cm} \times 30 \mathrm{~cm}$ packed with Hitachi gel \#3040. Carotenoids in the effluent were monitored at $450 \mathrm{~nm}$ with the UV detector, a Hitachi model 200 spectrophotometer, which was equipped with a micro flow cell of $10 \mathrm{~mm}$ light path. Two solvents were used for HPLC: 1) solvent $\mathrm{A}$, a mixture of equal volumes of $n$ hexane and benzene and 2) solvent B, acetone. Carotenoids were eluted with solvent A containing an increasing concentration of solvent $\mathrm{B}$ in a linear gradient reaching $100 \%$ after $60 \mathrm{~min}$. Elution speed was kept constant at $0.6 \mathrm{ml}$ per min. The sample volume injected changed from 5 to $20 \mu \mathrm{l}$.

A typical chromatogram of HPLC of carotenoids in green leaves is shown in Fig. 1. Usually seven peaks of the major components were observed. Sometimes minor ones appeared. Peaks 1, 3, and 6 were identified as carotenes (mainly $\beta$-carotene), lutein, and neoxanthin respectively by comparing their absorption spectra to those of the authentic carotenoids. Peak 4 was deduced to be antheraxanthin $\quad(5,6$-epoxy-5,6-dihydro- $\beta, \beta$-carotene-3,3'-diol) from the retention time, absorption maximum, and positive hydrochloric acid test for 5,6-epoxide. ${ }^{20)}$ Peak 5 was

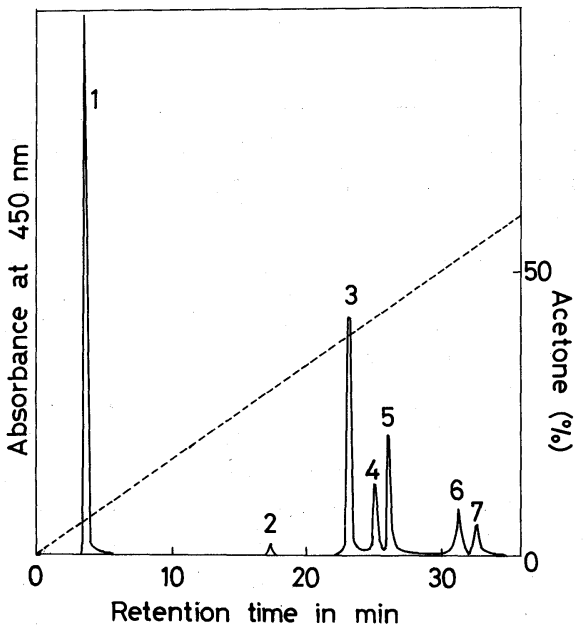

Fig. 1. Typical HPLC Chromatogram of Leaf Carotenoids in Summer (Perilla).

For chromatographic conditions see the text.

+ Biochemical Studies on Carotenoid XV. For Part XIV, see ref. 6. 
Table I. Composition of Leaf Carotenoids in Summer and in Winter

\begin{tabular}{|c|c|c|c|c|c|c|c|}
\hline Plants & $\begin{array}{l}\text { Carotene } \\
(\%)\end{array}$ & $\begin{array}{l}\text { Lutein } \\
(\%)\end{array}$ & $\begin{array}{l}\text { Anthera- } \\
\text { xanthin } \\
(\%)\end{array}$ & $\begin{array}{c}\text { Viola- } \\
\text { xanthin } \\
(\%)\end{array}$ & $\begin{array}{c}\text { Neo- } \\
\text { xanthin } \\
(\%)\end{array}$ & $\begin{array}{l}\text { Crocetin } \\
(\%)\end{array}$ & $\begin{array}{c}\text { Total carot. } \\
\text { ( } \mu \mathrm{g} / 10 \mathrm{~g} \text { fresh } \\
\text { weight })\end{array}$ \\
\hline \multicolumn{8}{|l|}{ (In summer) } \\
\hline $\begin{array}{l}\text { Carrot (Daucus carota } \\
\quad \text { var. sativus) }\end{array}$ & 45.5 & 28.2 & 8.5 & 9.1 & 8.7 & 0 & 743.5 \\
\hline Maize (Zea mays L.) & 50.0 & 37.0 & 6.3 & 4.2 & 2.5 & 0 . & 1389.0 \\
\hline $\begin{array}{l}\text { Soya (Glycine max } \\
\text { MERRILL) }\end{array}$ & 50.6 & 33.6 & 6.3 & 3.3 & 5.4 & 0.8 & 1376.0 \\
\hline $\begin{array}{l}\text { Perilla (Perilla frutescens } \\
\quad \text { viridis MAKINO) }\end{array}$ & 41.4 & 26.0 & 8.8 & 13.7 & 6.0 & 4.0 & 2233.0 \\
\hline $\begin{array}{l}\text { Cherry (Prunus yedoensis } \\
\text { Matsum.) }\end{array}$ & 36.1 & 35.3 & 5.7 & 16.6 & 6.3 & 0 & 2142.4 \\
\hline $\begin{array}{l}\text { Maple (Acer palmatum } \\
\text { THUNB.) }\end{array}$ & 36.4 & 40.7 & 5.6 & 11.1 & 6.3 & 0 & 3158.4 \\
\hline $\begin{array}{l}\text { Azalea (Rhododendron } \\
\text { indicum SwEET) }\end{array}$ & 30.1 & 33.9 & 8.4 & 13.6 & 9.1 & 0 & 1436.0 \\
\hline $\begin{array}{l}\text { Spindle tree (Euonymus } \\
\text { japonica THUNB.) }\end{array}$ & 28.9 & 34.2 & 8.0 & 15.6 & 13.2 & 0 & 630.8 \\
\hline \multicolumn{8}{|l|}{ (In winter) } \\
\hline \multicolumn{8}{|l|}{ Radish (Raphanus sativus } \\
\hline $\begin{array}{l}\text { L. var. acanthiformis } \\
\text { MAKINO) }\end{array}$ & 28.4 & 47.7 & 8.0 & 8.6 & 7.3 & 0 & 1058.0 \\
\hline $\begin{array}{l}\text { Lettuce (Lactuca scariola } \\
\text { L. var. sativa } \text { BISCH) }\end{array}$ & 28.5 & 44.5 & 8.8 & 9.9 & 8.3 & 0 & 1019.5 \\
\hline $\begin{array}{l}\text { Cabbage (Brassica oleracea } \\
\text { L. var. capitata L.) }\end{array}$ & 17.9 & 36.3 & 15.3 & 14.2 & 13.5 & 0 & 1731.3 \\
\hline $\begin{array}{l}\text { Leaf mustard (Brassica } \\
\text { juncea CzEM. et Coss.) }\end{array}$ & 20.3 & 33.0 & 18.9 & 15.2 & 6.2 & 0 & 2175.3 \\
\hline $\begin{array}{l}\text { Azalea (Rhododendron } \\
\text { indicum SWEET) }\end{array}$ & 22.1 & 42.1 & 11.9 & 11.2 & 5.2 & 0 & 2022.0 \\
\hline $\begin{array}{l}\text { Spindle tree (Euonymus } \\
\text { japonica THUNB.) }\end{array}$ & 34.5 & 42.1 & 9.9 & 7.5 & 6.1 & 0 & 789.5 \\
\hline
\end{tabular}

identified as violaxanthin by the retention time, absorption maximum, and positive hydrochloric acid test. Peak 7 was presumed to be crocetin, $^{21)}$ peak 2 contained no carotenoid.

When $\beta$-carotene solutions of known concentrations in solvent A were subjected to HPLC, a linear relationship was observed between the quantities of $\beta$-carotene and the peak areas in those chromatograms up to $200 \mathrm{ng}$ of $\beta$ carotene. Therefore, an equation, $C=124 \times S / f$, can be set up, in which ' $C$ ', ' $S$ ' and ' $f$ ' were starting carotenoid quantity (ng), chromatographic peak area $\left(\mathrm{cm}^{2}\right)$ calculated by the half width method, and a correction factor, respectively. The correction factors were determined by ratios of $E_{1 \mathrm{~cm}}^{1 \%}$ of each carotenoid at $450 \mathrm{~nm}$ in solvent A to that of $\beta$-carotene $\left(E_{1 \mathrm{~cm}}^{1 \%}=2590\right)$ at the same wavelength, and values determined were $1.0,0.87,0.86,0.86,0.50$, and 1.67 for $\beta$-carotene, lutein, antheraxanthin, violaxanthin, neoxanthin, and crocetin, respectively. The constant in the equation, 124, may change with chromatographic conditions.
The recovery of $\beta$-carotene was over $97 \%$. The errors inherent in the chromatographic analysis were within a few per cent; which mainly depended on the errors of injection volume. A detection limit in this analytical system was about $2 \mathrm{ng}$ for $\beta$-carotene. If one expects to obtain reproducible results, however, an injection quantity above $10 \mathrm{ng}$ for each carotenoid is necessary. Standard deviations throughout the analyses (three samples) were $4.3,12.1,11.2,6.3$, and $15.4 \%$ for $\beta$-carotene, lutein, antheraxanthin, violaxanthin, and neoxanthin, respectively.

Carotenoids in leaves of some species were quantitatively analyzed by this method (Table I). In annual plants, $\beta$-carotene was predominant in summer, while lutein was predominant in winter. In leaves of almost all the species of three tested more lutein was found than $\beta$ carotene, but lutein contents usually increase in quantitative ratio to $\beta$-carotene in winter. The variation between the amounts of $\beta$-carotene and lutein is considered to be caused by differences of both temperature and light 
intensity.

Acknowledgment. The author thanks Dr. S. Inaba in Okayama University for his advice on HPLC analysis. He also wishes to thank Mr. T. Ueda and F. Kishi in his laboratory for technical assistance.

\section{REFERENCES}

1) S. Takagi, M. Shiroishi and T. Takagi, Agric. Biol. Chem., 44, 2111 (1980).

2) S. Takagi, M. Shiroishi and T. Takagi, Agric. Biol. Chem., 45, 1159 (1981).

3) S. Takagi, K. Takeda and T. Takagi, Agric. Biol. Chem. 46, 399 (1982).

4) S. Takagi, K. Takeda, K. Kameyama and T. Takagi, Agric. Biol. Chem., 46, 2035 (1982).

5) S. Takagi, K. Takeda and M. Shiroishi, Agric. Biol. Chem., 46, 2217 (1982).

6) S. Takagi and K. Takeda, Agric. Biol. Chem., 47, 1435 (1983).

7) A. H. Kiyoko, A. Eidiomer and M. Silvania vez de Melo, Colet. Inst. Technol. Aliment, 11, 97 (1980).

8) I. Stewart and T. A. Wheaton, J. Chromatogr ${ }_{s}, 55$, 325 (1971).
9) R. Moneger, Physiol. Veg., 6, 367 (1968).

10) K. A. Buckle and F. M. Rahman, J. Chromatogr., 171, 385 (1979).

11) L. R. Snyder, Chromato. Revs., 7, 1 (1965).

12) J. E. Paanakker, J. C. Kreak and H. Poppe, J. Chromatogr., 149, 111 (1978).

13) B. H. Davies and E. I. Mercer, J. Chromatogr., 46, 161 (1970).

14) K. E. Eskins, C. R. Scholfield and H. J. Dutton, J. Chromatogr., 135, 217 (1977).

15) S. Takagi, Sci. Rep. Fac. Agr. Okayama Univ., 49, 35 (1977).

16) M. F. Bacon and M. Holden, Phytochemistry, 6, 193 (1967).

17) S. Liaaen-Jensen, "Carotenoid," ed. by O. Isler, Birkhauser Verlag, Basel \& Stuttgart, 1971, pp. $61 \sim 188$.

18) S. Otani, "Plant Pigments," ed. by K. Hayashi, Yokendo, Tokyo, 1980, p. 208.

19) J. F. G. M. Wintermans and A. de Motas, Biochim. Biophys. Acta, 109, 448 (1965).

20) A. L. Curl and G. F. Bailey, J. Agric. Food Chem., 9, 403 (1961).

21) S. Takagi and M. Shiroishi, Sci. Rep. Fac. Agr. Okayama Univ., 40, 75 (1972). 